\title{
The Relationship Between Motivation and Interest of Village Youth to Work in the Agricultural Sector in Paguyaman District, Boalemo Regency
}

\author{
Winarti Ibrahim ${ }^{1}$, Moh. Muchlis Djibran ${ }^{1}$, Merita Ayu Indriant ${ }^{1}$, Yusriyah Atikah Gobel ${ }^{1}$ \\ Email: winarti.ibrahim@yahoo.com \\ ${ }^{1}$ Agribusiness Study Program, Faculty of Agricultural Sciences, Muhammadiyah \\ University of Gorontalo, Indonesia
}

\begin{abstract}
Motivation is a drive that comes from within and from outside that can affect youth to work in the agricultural sector. This research was conducted in Paguyaman District. The purpose of this study was to determine the relationship between motivation and the interest of village youth to work in the agricultural sector. Analysis of the data used is relationship analysis (Chi-Square). The results showed that there was no relationship between motivation and interests of youth with a value of $\mathrm{x} 2$ count (4.779) smaller than the value of $\mathrm{x} 2$ table (9.487), so it can be concluded that $\mathrm{H} 1$ is rejected and $\mathrm{H} 0$ is accepted.
\end{abstract}

Keywords: Motivation, Interest, Youth, Agriculture Sector

Received : November 17, 2020

Received in Revised: December 2, 2020

Accepted: December 14, 2020

\section{Introduction}

Indonesia is a developing country with the agricultural sector as a source of livelihood for its population, thus most of the population depends on the agricultural sector for their livelihood. The fact is that most of the land use in the territory of Indonesia is designated as agricultural land and most of the people depend on the agricultural sector for their livelihoods. The agricultural sector has a very important role in the Indonesian economy, this is because the agricultural sector functions as the basis or basis for economic development (Faqih, 2009; Suberu et al., 2015; Kosenchuk et al., 2019).

Motivation is an effort to increase enthusiasm, direct and strengthen one's soul to achieve a certain goal. Motivation must exist in everyone because high motivation will make it easier for someone to achieve what he or she achieves. Interest must exist in a person, because interest is a person's initial capital before doing activities to achieve a goal. As an example of someone who is interested in agricultural activities, that person will have more attention and have greater curiosity. According to Handoko (2000), motivation is a state in a person's personality that encourages the individual's desire to carry out certain activities to achieve a goal. Meanwhile, according to Sutikno (2012), motivation is a driving force to carry out an activity. Meanwhile, according to Alma (2010), explaining that motivation is the willingness to do something, and according to Mardianto (2012), motivation can be interpreted as an encouragement or desire that can be achieved with certain behaviors in an effort.

According to Yuniarsih (2008), motivation is a psychological process that exists within everyone, a driving force that will make money or not, while according to Arranirti and Izatunnisa (2018), work motivation is the provision of a driving force or a group of people who 
create excitement so that willing to work together to achieve certain goals in accordance with what he wants.

Interest is a sense of preference and a sense of attachment to a thing or activity, without being told. Interest is basically the acceptance of a relationship between oneself and something outside oneself. The stronger or closer the relationship, the greater the interest. A person's interest is influenced by internal factors such as concentration, desire, motivation and needs (Slameto, 2013).

There must be motivation and encouragement for youth to be interested and motivated to work in the agricultural sector (Abdullah \& Sulaiman, 2013; Bednař́ková et al., 2016). In general, rural youth are tenacious and hardworking people. However, the current problem is that rural youth are less motivated to work in the agricultural sector and are more interested in working in other fields. Previous research on youth participation in huyula conservation has been carried out by Abas (2017) with the aim of explaining youth participation in agricultural huyula activities. Based on the description above, the researcher is interested in conducting research with the aim of knowing the relationship between the motivation and interest of youth to work in the agricultural sector.

\section{Methods}

This research will be carried out in Tenilo Village, Balate Jaya Village, Huwongo Village, Bongo Empat Village, Bualo Village, Paguyaman District, Boalemo Regency. The research location was chosen purposively with several considerations, namely: 1) that the research location is a potential area for agricultural development, 2) the research location is one of the locations that has quite a lot of village youth, namely 2641 youth. This research was conducted for two months, from August to September 2018. The population in this study is youth who live in Paguyaman sub-district. The youth selected are youths aged 15-30 years. The population in this study amounted to 98 youths.

The sampling technique used is the method of random sampling (Simple Random Sampling). According to Amirullah (2015), the sample was obtained by a random procedure from the sampling frame. This method is similar to the lottery system, where the names are placed in a container and the container is shuffled. The names of the winners are taken in a non-biased manner. Performing simple random sampling, researchers can create a sampling frame in which each element is grouped in a unique identification number. The total population in this study was 98 youth. This study aims to determine the level of motivation and interest of village youth in working in the agricultural sector in Paguyaman District, Boalemo Regency.

Data analysis used in this study consisted of descriptive analysis and non-parametric analysis. Through these two analyzes, we are able to explain the relationship between motivation and interest in village youth to work in the agricultural sector in Paguyaman District, Boalemo Regency. The analytical technique used in this study is categorical/qualitative data analysis with the Chi-Square correlation formula used to analyze the relationship between the independent variable and the dependent variable using the SPPS application with a $5 \%$ confidence level (Sujarweni, 2015).

Chi-Square used for comparison (comparative) variables is the following formula.

$$
\frac{n\left(a d-a c-\frac{1}{2} n\right)^{2}}{(a+b)(a+c)(b+d)(c+d)}
$$


Where:

$$
\begin{aligned}
& \mathrm{n}=\text { number of samples } \\
& \mathrm{a}=\text { low motivation } \\
& \mathrm{b}=\text { high motivation } \\
& \mathrm{c}=\text { low interest } \\
& \mathrm{d}=\text { high interest }
\end{aligned}
$$

Criterion:

$$
\begin{aligned}
& \text { If } x^{2} \text { count }>x^{2} \text { table }=\text { Ho rejected } \\
& \text { If } x^{2} \text { count }<x^{2} \text { tables }=\text { Ho received }
\end{aligned}
$$

\section{Results and Discussion}

\section{The Relationship Between Youth Motivation and Interest}

Based on the research results, the relationship between youth motivation and interest to work in the agricultural sector can be done by cross tabulating / close tab between the two variables, namely motivation with youth interest. Based on the results of the Crosstabulation analysis, it can be seen that the influence of the distribution of motivation on youth interest is that people who have motivation in the disagree category are zero meaning no youth choose to disagree, then the agree category is 2 youths and the category strongly agrees is zero meaning no youth choose in the strongly agree category, then the number of motivations in the disagree category are 2 youths. For motivation in the doubtful category there are 6 youths who disagree, then 42 youths who agree, and for strongly agreeing there are 10 youths, the total motivation in the doubtful category is 58 youths.

\begin{tabular}{|c|c|c|c|c|c|}
\hline & \multicolumn{3}{|c|}{ Interest } & \multirow{2}{*}{ Total } \\
\hline & & TS & $\mathrm{S}$ & SS & \\
\hline \multirow[t]{3}{*}{ Motivation } & $\mathrm{TS}$ & 0 & 2 & 0 & 2 \\
\hline & RR & 6 & 42 & 10 & 58 \\
\hline & $\mathrm{S}$ & 2 & 34 & 2 & 38 \\
\hline \multicolumn{2}{|l|}{ Total } & 8 & 78 & 12 & 98 \\
\hline
\end{tabular}

Motivation in the agree category there are 2 youths who disagree, then there are 34 youths who agree and there are 2 youths who choose strongly agree, then the number of motivations in the agree category is 38 youths. If we add down the number of categories that disagree with interest, there are 8 youths and for the agree category there are 78 youths while for strongly disagree there are 12 youths (Table 1).

Table 1. Crosstabulation hypothesis test results

Source: Processed from primary data, 2018

\section{Chi-Square Test}

The Chi-Square test was conducted to determine the relationship between the motivation and interest of young people to work in the agricultural sector. To find out both can be done hypothesis testing as follows:

Ho: There is no relationship between motivation and youth interest to work in the agricultural sector. 
H1: There is a relationship between motivation and youth interest to work in the agricultural sector.

Based on the results of the Chi-Square test motivation with youth interest, obtained a value x2count of 4,779 (Table 18 and Appendix 7). This can be interpreted that x2counts < from x2tables $(9,487)$, so it can be concluded that Ho accepted or there is no relationship between motivation and the interest of village youth to work in the agricultural sector in Paguyaman district.

Table 2. Chi Square Test Results for The Relationship between Youth Motivation and Interests

\begin{tabular}{|c|c|c|c|}
\hline & Value & df & Asymp. Sig. (2-sided) \\
\hline Pearson Chi-Square & $4,779^{\mathrm{a}}$ & 4 & 0,331 \\
\hline Likelihood Ratio & 5,485 & 4 & 0,241 \\
\hline Linear-by-Linear Association & 0,394 & 1 & 0,530 \\
\hline N of Valid Cases & 98 & & \\
\hline
\end{tabular}

Source: Processed from primary data, 2018

\section{Conclusion}

Based on the results of research and discussion can be concluded that Based on the results of statistical calculations using chi-square in this study suggests that there is no relationship between motivation and interest of youth $\left(r_{\text {calculate }} 4,779 £ r_{\text {table }} 9,487\right)$ means $\mathrm{H}_{1}$ rejected and $\mathrm{H}_{0}$ accepted. It is hoped that the government will provide roles and support and motivation for youth to work in the agricultural sector by involving youth in education and training counseling activities on agriculture and providing training on agricultural technology and agricultural entrepreneurship, so as to increase youth knowledge in order to develop the village itself.

\section{References}

Abas, E. (2017). Motivasi Pemuda dalam Pelestarian Huyula (Gotongroyong) di Kecamatan Asparaga Kabupaten Gorontalo Thesis: Universitas Muhammadiyah Gorontalo.

Abdullah, A. A., \& Sulaiman, N. N. (2013). Factors that influence the interest of youths in agricultural entrepreneurship. International Journal of business and Social science, 4(3), 288-302.

Alma, B. (2010). Kewirausahaan. Bandung: Alfabeta.

Amirullah. (2015). Populasi dan Sampel (Pemahanan, Jenis Dan Teknik). Bayumediya Publishing Malang.

Bednaříková, Z., Bavorova, M., \& Ponkina, E. V. (2016). Migration motivation of agriculturally educated rural youth: The case of Russian Siberia. Journal of rural studies, 45, 99-111.

Faqih, A. (2009). Pengaruh Pengembangan Sektor Pertanian terhadap Kesempatan Kerja Dan Distribusi Pendapatan Di Provinsi Jawa Tengah, Thesis: Universitas Negri Searang.

Handoko, T. (2000). Manajemen. BPFE: Yogyakarta.

Kosenchuk, O., Shumakova, O., Zinich, A., Shelkovnikov, S., \& Poltarykhin, A. (2019). The development of agriculture in agricultural areas of Siberia: Multifunctional character, environmental aspects. Journal of Environmental Management \& Tourism, 10(5 (37)), 991-1001. 
Mardianto, A. (2012). Recruitmen Analysis. Pinasthika. Jakarta.

Slameto. (2013). Belajar \& Faktor-faktor Yang Mempengaruhinya. Rineka Cipta. Jakarta.

Suberu, O. J., Ajala, O. A., Akande, M. O., \& Olure-Bank, A. (2015). Diversification of the Nigerian economy towards a sustainable growth and economic development. International journal of Economics, finance and Management sciences, 3(2), 107114.

Sujarweni, V, W. (2015). Statistik Untuk Kesehatan. Gava Media.

Sutikno, S, M. (2012). Manajemen Pendidikan. Holistica. Lombok 